\title{
Diversity and phylogenetic analysis of endosymbiotic bacteria of the date palm root borer Oryctes agamemnon (Coleoptera: Scarabaeidae)
}

Wael S El-Sayed ${ }^{1,2^{*}}$ and Reda A Ibrahim ${ }^{1,3}$

\begin{abstract}
Background: The date palm root borer Oryctes agamemnon (Coleoptera: Scarabaeidae) is one of the major pests of palms. In Saudi Arabia, both larvae and adults of Oryctes are particularly troublesome, especially during the establishment of young date palm orchards. Endosymbiotic bacteria are known to have a key role in food digestion and insecticide resistance mechanisms, and therefore are essential to their host insect. Identification of these bacteria in their insect host can lead to development of new insect pest control strategies.

Results: Metagenomic DNA from larval midgut of the date palm root borer, O. agamemnon, was analyzed for endosymbiotic bacterial communities using denatured gradient gel electrophoresis (DGGE) utilizing 16S rRNA genes. The DGGE fingerprints with metagenomic DNA showed predominance of eleven major operational taxonomic units (OTUs) identified as members of Photobacterium, Vibrio, Allomonas, Shewanella, Cellulomonas, and Citrobacter, as well as uncultured bacteria, including some uncultured Vibrio members. DGGE profiles also showed shifts in the dominant bacterial populations of the original soil compared with those that existed in the larval midguts. The endosymbiotic bacterial community was dominated by members of the family Vibrionaceae (54.5\%), followed by uncultured bacteria (18.2\%), Enterobacteriaceae (9.1\%), Shewanellaceae (9.1\%), and Cellulomonadaceae (9.1\%). Phylogenetic studies confirmed the affiliation of the dominant OTUs into specified families revealed by clustering of each phylotype to its corresponding clade. Relative frequency of each phylotype in larval midguts revealed predominance of Vibrio furnisii and Vibrio navarrensis, followed by uncultured bacterial spp., then Cellulomonas hominis, Shewanella algae, and Citrobacter freundii.
\end{abstract}

Conclusion: Analysis of metagenomic DNA for endosymbiotic bacterial communities from the midgut of Oryctes larvae showed strong selection of specific bacterial populations that may have a key role in digestion, as well as other benefits to the larvae of $O$. agamemnon. Determination of the distinct endosymbiotic community structure and its possible biological functions within the insect could provide us with basic information for future pest control research.

Keywords: Oryctes agamemnon, Endosymbionts, $16 \mathrm{~S}$ rRNA gene, DGGE

\footnotetext{
* Correspondence: waelsme@yahoo.com

'Biology Department, Faculty of Science, Taibah University, Almadinah

Almunawarah 344, Saudi Arabia

${ }^{2}$ Microbiology Department, Faculty of Science, Ain Shams University, Cairo

11566, Egypt

Full list of author information is available at the end of the article
}

\section{Biomed Central}

(c) 2015 El-Sayed and Ibrahim; licensee BioMed Central. This is an Open Access article distributed under the terms of the Creative Commons Attribution License (http://creativecommons.org/licenses/by/4.0), which permits unrestricted use, distribution, and reproduction in any medium, provided the original work is properly credited. The Creative Commons Public Domain Dedication waiver (http://creativecommons.org/publicdomain/zero/1.0/) applies to the data made available in this article, unless otherwise stated. 


\section{Background}

Several insect pests attack date palm (Phoenix dactylifera L.) orchards, causing serious damage and economic losses. In many Arabian countries, three species of rhinoceros beetles, Oryctes (Coleoptera: Scarabaeidae), O. elegans, O. agamemnon and O. rhinoceros, are known to infest date palm orchards [1]. The most widespread is O. agamemnon, which is a root borer in its larval stage and a frond borer in the adult stage. The other two species, O. rhinoceros and O. elegans, are fruit stalk borers and can also act as root borers [2]. Oryctes spp. have a wide host range, attacking and causing serious damage and crop loss on many hosts, including date palm, coconut palm, betel nut, sago palm and oil palm [3]. Recently, Oryctes spp. have emerged as major pests of different date palm cultivars. In Saudi Arabia, both larvae and adults of Oryctes are particularly troublesome, especially during the establishment of young date palm orchards. The development time of the larval stage is long and may extend for several years in some species. The larvae feed on roots and rotten wood whereas the adults feed on nectar, plant sap and fruit [4-7].

Certain mutualists may influence host plant range and enable insect pests to modify plant physiology for their own benefit. There is increasing evidence for the role of microbial mutualistic symbioses in insect-plant interactions [8]. The horizontal transmission of mutualists among their host insects can be achieved through a route involving its host plant. Where this transmission occurs, the insect mutualist might either become a plant pathogen and damage the plant or change the way the plant interacts with its natural enemies and host competitors [9].

Insect intestinal tracts harbor rich communities of nonpathogenic microorganisms [10]. A single gut can harbor $10^{5}-10^{9}$ prokaryotic cells [11] that have been affiliated to twenty-six phyla, at least for the insects studied to date. It is increasingly evident that insect microbiota are essential for normal growth and development [12]. It has been shown that about $65 \%$ of insects possess symbiotic bacteria. Wolbachia spp. is the most commonly reported genus [13-15]. The symbiotic relationship between bacteria and insects varies from being mutualistic and commensal to pathogenic [16,17]. Based on their role, intracellular symbionts in insects are classified as primary or secondary endosymbionts. Primary (obligate) symbionts are essential for the insect due to their role in nutrient supplementation, whereas secondary symbionts have a useful but not essential role for insect survival $[18,19]$. Insect endosymbionts are detected in specific organs referred to as bacteriomes or mycetomes, usually resulting in a strict vertical transmission from mother to offspring.

Understanding relationships between endosymbiotic bacteria and their insect hosts is not only relevant from an evolutionary view, but can also lead to the identification of new targets for insect pest control [20]. Since many of the relevant endosymbionts cannot be cultured, their functional characterization and/or identification has been difficult. Certain symbionts have been developed as biological control agents and were found to be effective against Chagas disease vectored by Rhodnius prolixus. In this example, the endosymbiotic organism, Rhodococcus rhodnii was genetically transformed to express an anti-trypanosomal output in the insect gut [21].

The date palm root borers of the genus Oryctes are regarded as devastating and invasive pests in a wide variety of palms worldwide. Little is known about the presence of endosymbionts in the genus Oryctes. Exploring bacteria-insect associations in this regard would be useful for potential insect pest control. For example, if obligate endosymbionts exist in Oryctes, then eliminating them using baits could be a potential control strategy. Investigation of endosymbiosis in this genus may help to understand the host-symbiont interactions and the evolution of different reproductive strategies in these beetles, and ultimately provide a future basis for development of novel pest management strategies. Therefore, the objective of this study was to analyze the diversity of the larval midgut microbiota of the date palm root borer, O. agamemnon.

\section{Results and discussion}

\section{Endosymbionts of Oryctes agamemnon larvae}

Microbial diversity is defined as the number of elements indicated by species or genes within a system [22]. Most of the microbial world within a system remains unexplored due to the existence of many uncultured bacteria species. Molecular-based approaches are useful for determining diversity of various bacterial populations [23-25]. Several molecular methods based on DNA analyses using polymerase chain reaction (PCR) followed by an analysis of the diversity of PCR products are available [26-28]. Polymerase chain reaction denatured gradient gel electrophoresis (PCR-DGGE) [26] in particular, has been regarded as a powerful genetic fingerprinting technique for evaluation of bacterial community structures in different environmental niches. PCR-DGGE analysis utilizing 16S rRNA genes usually yield patterns that reflect the composition of the dominant microorganisms, including the uncultured members [24]. DGGE has been widely used to investigate several bacterial patterns in soil [29], marine habitats [30], rhizosphere [31], grasslands [32], manure and fertilizers [33], and sites polluted with anthropogenic chemicals [34]. Bacterial diversity and community structure of insect endosymbiotic bacteria have not been investigated by DGGE previously. Therefore, we used DGGE in this study to investigate bacterial populations in the midgut of $O$. 
agamemnon larvae. The DGGE patterns obtained with total community DNA from larval midguts showed predominance of eleven major OTUs (Figure 1). DGGE profile of metagenomes belonging to five larval midguts showed the same pattern, confirming a stable and intact endosymbiotic bacterial community structure. DGGE was also used to investigate the distribution pattern of soil bacteria in larva-infested soil. DGGE fingerprinting showed changes in the dominant bacterial populations of the original soil compared with those that existed in the midguts. This shift could be attributed to the strong selection of specific bacterial populations that may have a key role in insect nutrition. The consistency of such midgut endosymbionts suggests the presence of O. agamemnonspecific microbiota. Andert et al. [35] addressed the

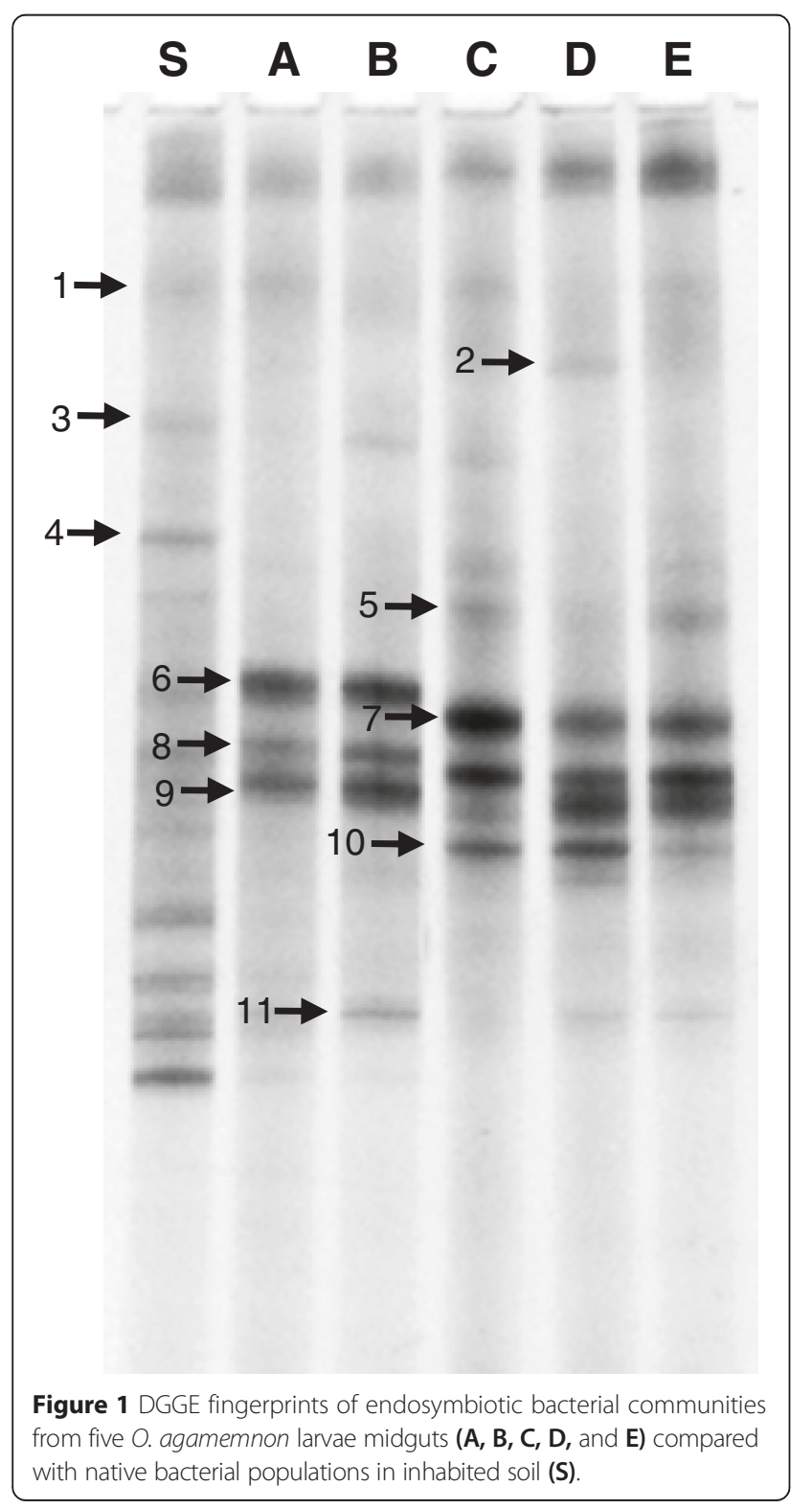

question whether or not the hindgut of the two closely related scarabs Pachnoda ephippiata and Pachnoda marginata, harbors a specific bacterial microbiota. Terminal restriction fragment length polymorphism (T-RFLP) analysis showed that in both species, the hindgut bacterial community strongly differs from that in the midgut, food soil, and fecal pellets. It was concluded that high intraand interspecific similarities between the T-RFLP profiles of different larvae indicate the presence of a hindgutspecific microbiota.

\section{Endosymbiotic bacterial community structure}

Endosymbiotic bacterial community structure for insects in general based on culture dependent methods will remain uncertain. Culture-independent methods allow a deeper understanding of the composition of microbial communities in different ecosystems [23]. In this study we examined the endosymbiotic bacterial community structure of date palm root borer larvae with DGGE for rapid comparison of data from many communities and specific phylogenetic information derived from excised bands [27]. Sequence analysis of $16 \mathrm{~S}$ rRNA gene fragments obtained from DGGE revealed the identity of the endosymbionts in the larval midgut of O. agamemnon. Based on BLAST best similarity matches, phylotypes frequently detected in fingerprinting analysis have been affiliated to Photobacterium sp., Vibrio sp., Allomonas sp., Shewanella sp., Cellulomonas sp., and Citrobacter sp., as well as some uncultured bacteria, including uncultured Vibrio sp. (Table 1). These bacteria might be responsible for palm tissue fermentation in the tunnels where $O$. agamemnon larvae thrive and might have a key role in the insect's nutrition. Many of the Enterobacteriaceae produce digestive enzymes and therefore have a role in insect nutrition [36].

Gut bacteria have been reported to exert many useful functions, such as preventing disease, degrading insecticides, and directly or indirectly contributing to food digestion [15]. Food materials may be important in regulating the dynamics of the bacterial community within the insect gut. For example, S. marcescens is a facultative anaerobe that aids in consuming oxygen at the periphery of the Formosan termite's stomach, thereby maintaining a habitable gut for the strict anaerobes that digest cellulose [37]. In addition to aiding digestion, Citrobacter detected in our study is believed to have the same role in establishing anaerobic conditions for the succession of Shewanella spp. involved in anaerobic fermentation of ingested materials.

Analysis of larval midgut bacterial populations in O. agamemnon revealed a predominance of members belonging to the genus Vibrio. Dominance of certain bacterial taxa as endosymbionts in some insects has been reported. Using sequence-based bacterial typing, 
Table 1 Bacterial species identified in the midgut of 0 . agamemnon larvae

\begin{tabular}{|c|c|c|c|c|c|}
\hline \multirow{2}{*}{$\begin{array}{l}\text { DGGE } \\
\text { band }\end{array}$} & \multirow[t]{2}{*}{ Accession no. } & \multicolumn{3}{|l|}{ Closest matches } & \multirow[t]{2}{*}{ Phylogenetic affiliation } \\
\hline & & Identity & Accession no. & Similarity (\%) & \\
\hline \multirow[t]{3}{*}{1} & LC009469 & Photobacterium ganghwense FR1311 & NR043295 & 100 & Gammaproteobacteria/Vibrionaceae \\
\hline & & Photobacterium sp. & AB583193 & 100 & Gammaproteobacteria/Vibrionaceae \\
\hline & & Photobacterium sp. RSBAUOCAS0005B & HM641040 & 100 & Gammaproteobacteria/Vibrionaceae \\
\hline \multirow[t]{3}{*}{2} & LC009470 & Vibrio fluvialis MBTD-CMFRI-Vf05 & KF317830 & 100 & Gammaproteobacteria/Vibrionaceae \\
\hline & & Vibrio sp. BTOK10 & JQ923505 & 100 & Gammaproteobacteria/Vibrionaceae \\
\hline & & Vibrio vulnificus MP-4 & AY911393 & 100 & Gammaproteobacteria/Vibrionaceae \\
\hline \multirow[t]{3}{*}{3} & LC009471 & Photobacterium ganghwense FR1311 & NR043295 & 100 & Gammaproteobacteria/Vibrionaceae \\
\hline & & Vibrio fortis H083 & KJ577078 & 100 & Gammaproteobacteria/Vibrionaceae \\
\hline & & Uncultured bacterium clone SWH04_PR & JQ480712 & 98 & Gammaproteobacteria/Vibrionaceae \\
\hline \multirow[t]{3}{*}{4} & LC009472 & Uncultured bacterium clone BT12G08 & KC208438 & 99 & Bacteria/Environmental sample \\
\hline & & Uncultured bacterium clone SWG11_MS & JQ480736 & 99 & Bacteria/Environmental sample \\
\hline & & Uncultured bacterium clone nbw223h08c1 & KF064992 & 99 & Bacteria/Environmental sample \\
\hline \multirow[t]{3}{*}{5} & LC009473 & Allomonas enterica JC102, D09-37 & FR837603 & 98 & Gammaproteobacteria/Vibrionaceae \\
\hline & & Uncultured Vibrio sp. clone D004025F04 & GU179548 & 98 & Gammaproteobacteria/Vibrionaceae \\
\hline & & Uncultured bacterium clone LGH02-B-135 & HQ916550 & 98 & Gammaproteobacteria/Vibrionaceae \\
\hline \multirow[t]{3}{*}{6} & LC009474 & Vibrio navarrensis AM37820 & KJ807107 & 100 & Gammaproteobacteria/Vibrionaceae \\
\hline & & Vibrio navarrensis 2544-86 & KJ807099 & 100 & Gammaproteobacteria/Vibrionaceae \\
\hline & & Vibrio navarrensis 1397-6T & KJ807092 & 100 & Gammaproteobacteria/Vibrionaceae \\
\hline \multirow[t]{3}{*}{7} & LC009475 & Vibrio sp. U15 & HF968434 & 100 & Gammaproteobacteria/Vibrionaceae \\
\hline & & Vibrio furnisii (ATCC 35016T) & X74704 & 100 & Gammaproteobacteria/Vibrionaceae \\
\hline & & Uncultured Vibrio sp. clone KR-SUC-9-A10 & AM183773 & 99 & Gammaproteobacteria/Vibrionaceae \\
\hline \multirow[t]{3}{*}{8} & LC009476 & Shewanella algae $\mathrm{H} 5$ & KM007068 & 99 & Gammaproteobacteria/Shewanellaceae \\
\hline & & Shewanella haliotis NIOT-CS16 & KJ371072 & 99 & Gammaproteobacteria/Shewanellaceae \\
\hline & & Shewanella sp. MPTDBS & KJ796480 & 99 & Gammaproteobacteria/Shewanellaceae \\
\hline \multirow[t]{3}{*}{9} & LC009477 & Cellulomonas hominis Puic5.18 & LM994741 & 99 & Actinobacteria/Cellulomonadaceae \\
\hline & & Cellulosimicrobium cellulans S17 & KJ947163 & 99 & Actinobacteria/ Promicromonosporaceae \\
\hline & & Cellulomonas aerilata JCM 16376 & AB910521 & 99 & Actinobacteria/Cellulomonadaceae \\
\hline \multirow[t]{3}{*}{10} & LC009478 & Citrobacter freundii C09 & KM222617 & 99 & Gammaproteobacteria/Enterobacteriaceae \\
\hline & & Citrobacter youngae GTC 01314 & AB741661 & 99 & Gammaproteobacteria/Enterobacteriaceae \\
\hline & & Citrobacter murliniae M-T-MRS_22 & JQ795823 & 99 & Gammaproteobacteria/Enterobacteriaceae \\
\hline \multirow[t]{3}{*}{11} & LC009479 & Uncultured bacterium clone SWH04_PR & JQ480712 & 98 & Bacteria/Environmental sample \\
\hline & & Uncultured bacterium clone BT12G08 & KC208438 & 99 & Bacteria/Environmental sample \\
\hline & & Uncultured bacterium clone SWG11_MS & JQ480736 & 99 & Bacteria/Environmental sample \\
\hline
\end{tabular}

Hirsch et al. [17] identified bacterial endosymbionts in four species of Otiorhynchus. More than $90 \%$ of all sequence reads belonged to the genus Rickettsia. Tagliavia et al. [38] analyzed the gut microbiota of larvae of the red palm weevil. High abundance of Enterobacteriaceae was detected. Fujiwara et al. [39] surveyed symbiotic bacteria from Bemisia tabaci species and reported the dominance of Rickettsia in all examined whitefly species.

In contrast to our results with larvae, in a study of gut microbiota of adult Oryctes monoceros by Desai and Bhamre [40], a completely different microbial population, except for Citrobacter, was reported, and included Dienococcus proteolyticus, Micrococcus varians, Micrococcus kristinae, Micrococcus roseus, Micrococcus lylae, Citrobacter amalonacticus, Corynebacterium xerosis and Bacillus fermentas.

Cellulolytic bacteria are important for digestion of cellulosic materials. In our study, Cellulomonas sp. has been detected as a member of the O. agamemnon midgut bacterial population indicating its involvement in the digestion process. Huang et al. [41] isolated strains of aerobic and facultatively anaerobic cellulolytic bacteria 
from the gut of Holotrichia parallela (Coleoptera: Scarabaeidae) larvae. The cellulolytic bacterial community was dominated by Proteobacteria, Actinobacteria, Firmicutes, and Bacteroidetes (1.45\%). However, Cellulomonas sp. in particular, was not detected among this community.

\section{Diversity of Oryctes agamemnon endosymbionts}

The versatility and diversity of insect-bacteria interactions leads to an enormous potential regarding the mechanisms for the modulation and control of insect pests with both medical and agricultural implications [42]. Through TFLP analyses of bacterial rRNA extracted from the guts of Harpalus pensylvanicus and Anisodactylus sanctaecrucis (Coleoptera: Carabidae), Lundgren et al. [8] revealed that gut-associated bacterial communities were of low diversity. The bacterial community in these beetles comprised Serratia sp., Burkholderia fungorum, $H$. alvei, Phenylbacterium sp., Caedibacter sp., Spiroplasma sp., Enterobacter strain B-14, and Weissella viridescens. Some of these organisms, but not all have been previously associated with insects. However, none of them has been detected in O. agamemnon, suggesting that their larvae have a unique bacterial community. In comparison to previously reported insect microbiota, our study revealed low diversity and a highly unique pattern for O. agamemnon microbiota.

The midgut bacterial populations of $O$. agamemnon larvae were taxonomically restricted to two major groups, with $80 \%$ of the natural bacterial microbiota composed of only three bacterial families within Gammaproteobacteria. The dominant bacterial taxa are members of Vibrionaceae (54.5\%), Enterobacteriaceae (9.1\%), and Shewanellaceae (9.1\%). In addition to Gammaproteobacteria, one family belonging to Actinobacteria was detected (Cellulomonadaceae $(9.1 \%)$ ). Host diet plays a major role in shaping the insect bacterial microbiota. Chandler et al. [43] found that Drosophilid flies have taxonomically restricted bacterial communities, with $85 \%$ of the natural bacterial microbiome composed of only a few bacterial families (Enterobacteriaceae, Lactobacillales and Acetobacteraceae). 18.2\% from the total bacterial population was detected as uncultured bacterial members. Several indices, including species richness and evenness, are used to describe the structural diversity of a community [44]. (Figure 2A) shows the diversity and richness of bacterial species of O. agamemnon larvae compared with those of the soil where the larvae live. The reduction in diversity and richness of bacterial species of larvae compared with soil was attributed to the selection of specific bacterial populations that may have a key role in food digestion for the benefit to the larvae. (Figure 2B) shows the relative frequency of each bacterial species and the predominance of Vibrio spp. among the endosymbiotic bacterial population.

\section{Phylogenetic analysis}

The 16S rRNA genes are used for phylogenetic affiliation of Eubacteria and Archaea. Partial sequences of $16 \mathrm{~S}$ rRNA gene of bacterial microbiota from the larval midgut of O. agamemnon have been analyzed. Sequences were compared with their closest matches with BLAST search tool to obtain the nearest phylogenetic neighbors. About 72.7\% of the bacterial community was assigned to Gammaproteobacteria. The remainder of the bacterial community was assigned to Actinobacteria (9.1\%) and uncultured bacterial members (18.2\%). Bacteria belonging to Gammaproteobacteria were classified as members of three families; Vibrionaceae, Enterobacteriaceae, and Shewanellaceae, with predominance of the former. Actinobacteria comprised only one family, Cellulomonadaceae enclosing Cellulomonas sp.

Tagliavia et al. [38] analyzed the gut microbiota of larvae of the red palm weevil. They assigned $98 \%$ of the total population to only three phyla: Proteobacteria, Bacteroidetes, and Firmicutes, and three main families (Enterobacteriaceae, Porphyromonadaceae and Streptococcaceae). Bacterial members have been identified as Dysgonomonas, Lactococcus, Salmonella, Enterobacter, Budvicia, Entomoplasma, Bacteroides and Comamonas. The major phylogenetic microbiota of the hindgut of $P$. ephippiata were identified through a $16 \mathrm{~S}$ rRNA gene clone library and revealed that Clostridia, Betaproteobacteria, and Bacteroidetes, followed by Bacillales and Deltaproteobacteria, were dominant.

In this research, phylogenetic studies confirmed the affiliation of dominant OTUs from O. agamemnon midgut to members of four distinct families, Vibrionaceae, Shewanellaceae, Enterobacteriaceae, and Cellulomonadaceae, revealed by clustering of each individual member to its corresponding group. (Figure 3) represents the phylogenetic tree based on 16S rRNA sequences analysis and showing the relationship between selected dominant phylotypes (OTUs) and representative species, along with other related genera. According to phylogenetic analysis, six phylotypes have been assigned to the family Vibrionaceae including, DGGE-OTU 1, 2, 4, 5, 7, and 11. DGGE-OTU 6 was identified as Vibrio member and clustered at a separate phylogenetic branch with Vibrio navarrensis indicating its close relation to that species in particular; and finally, DGGE-OTU 3 was specifically clustered with Vibrio fortis $\mathrm{H} 083$ and Vibrio sp. S4. Family Shewanellaceae was found to contain only one species, DGGE-OTU 8, with $99 \%$ sequence similarity to Shewanella sp. and phylogenetically clustered with Shewanella spp. branch. The phylotype DGGE-OTU 9 was affiliated to the Actinobacteria and assigned to $\mathrm{Cel}$ lulomonas sp. (99\%) or Cellulosimicrobium cellulans S17 (99\%). Enterobacteriaceae group was only represented by one phylotype, DGGE-OTU 10, that has been affiliated 

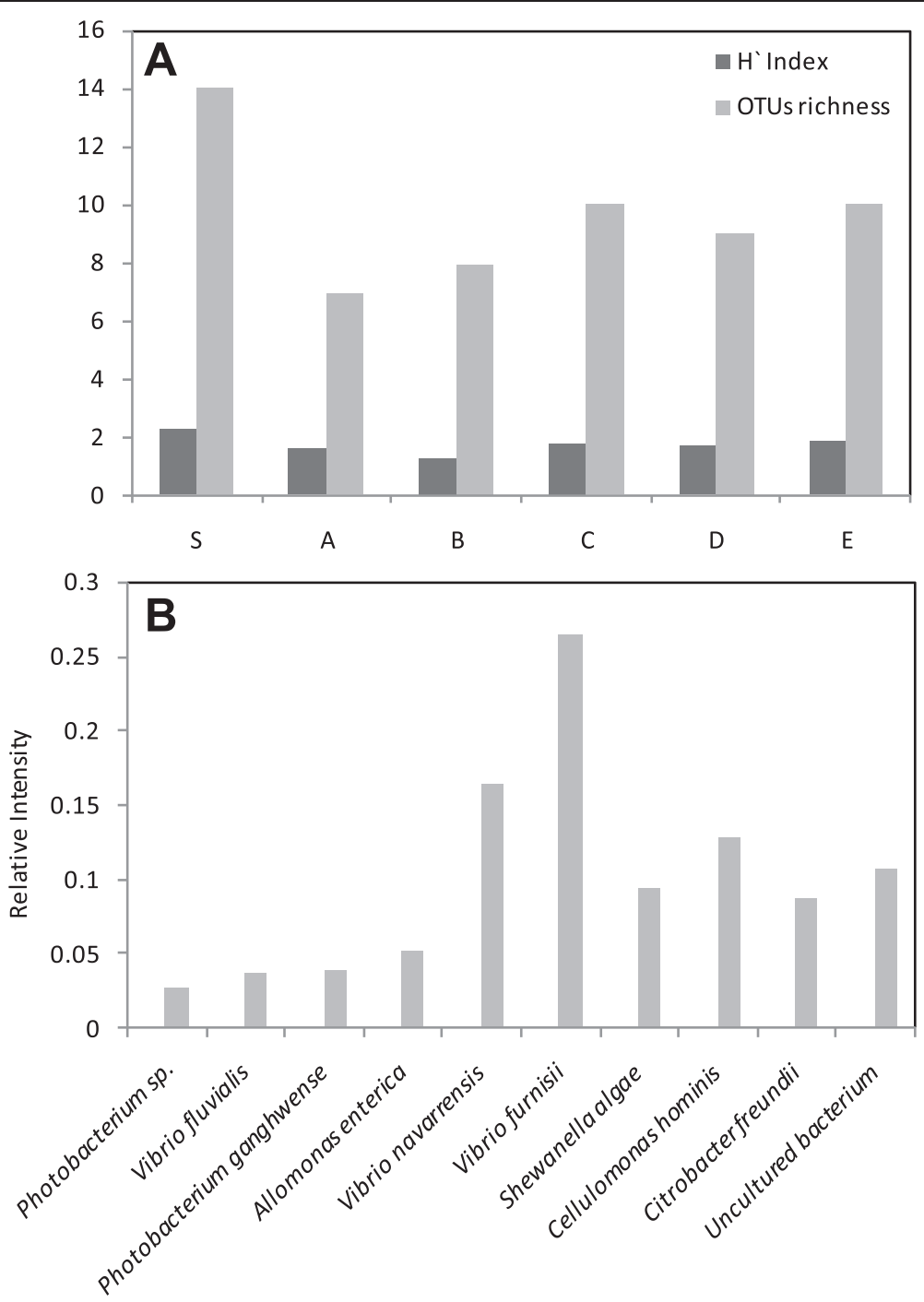

Figure 2 Numerical analysis for the diversity of the O. agamemnon endosymbionts. (A), DGGE OTUs richness and Shannon diversity index (H) determined from DGGE fingerprints of endosymbiotic bacterial communities of larvae midguts (A, B, C, D, and E) compared with soil bacteria (S). (B), Relative frequency of each phylotype in larvae midguts.

to Citrobacter sp. Phylogenetic analysis confirmed its relation to Enterobacteriaceae members like Enterobacter, Klebsiella, and Leclercia. Members of Enterobacteriaceae have been reported as frequent endosymbionts. Campbell et al. [45] studied the phylogeny of symbiotic bacteria of four weevil species (Coleoptera: Curculionidae) and showed that symbionts from taxonomically divergent weevils are mainly members of the Enterobacteriaceae. uncultured endosymbiotic bacteria were also detected in this study. DGGE-OTU 4 and 11 were assigned to uncultured bacterial members.

\section{Conclusions}

In conclusion, endosymbiotic bacteria are known to be involved in protecting their host insect against natural antagonists, contributing to insecticide resistance mechanisms, and aiding in food digestion and are, therefore, essential for normal growth and development of their host insect. In this regard, endosymbiotic bacteria could be manipulated, potentially offering new approaches for insect control. Therefore, identification of endosymbiotic bacteria of $O$. agamemnon is an important step in this process. Metagenomic DNA from midguts of Oryctes larvae was analyzed for endosymbiotic bacterial communities. Except for the Enterobacteriacaea group, Oryctes larvae were found to harbor unique endosymbiotic bacteria when compared with previously reported microbiota. Such distinct microbial community structure and its possible biological function within the insect will provide us with basic information for development of pest control strategies utilizing intrinsic endosymbiotic bacteria. Finally, there is an ultimate question 
Uncultured Vibrio sp. clone D004025F04 (GU179548)

DGGE-7 (LC009475)

Uncultured bacterium clone LCRSF-8F-f12 (KC712357)

Uncultured bacterium clone nbw223h08c1 (KF064992)

Vibrio vulnificus HG (GU727813)

Uncultured bacterium clone SWG11-MS (JQ480736)

DGGE-11 (LC009479)

DGGE-4 (LC009472)

Vibrio furnissii ATCC 35016T (X74704)

Vibrio sp. BTOK10 (JQ936967)

62 Vibrio furnissii U15 (HF968434)

Photobacterium sp. RSBAUOCAS0005B (HM641040)

Photobacterium sp. TKY1 (AB501122)

Photobacterium ganghwense FR1311 (NR043295)

DGGE-1 (LC009469)

Photobacterium sp. TKY4 (AB583193)

Vibrio cincinnatiensis CECT4216 (EU851051)

DGGE-2 (LC009470)

Vibrio fluvialis MBTD-CMFRI-Vf05 (KF317830)

DGGE-5 (LC009473)

Uncultured bacterium clone LGH02-B-135 (HQ916550)

Vibrio sp. FALF217 (EU655372)

DGGE-3 (LC009471)

53 Vibrio fortis H083 (KJ577078)

Vibrio sp. S4 (EU372926)

Vibrio navarrensis 1397-6T (KJ807092)

Uncultured bacterium clone G7DUZBG01BWCCW (JX941345)

95 DGGE-6 (LC009474)

58

Vibrio navarrensis AM37820 (KJ807107)

Vibrio navarrensis 2544-86 (KJ807099)

Shewanella sp. MPTDBS (KJ796480)

Shewanella haliotis NIOT-CS16 (KJ371072)

58

DGGE-8 (LC009476)

Shewanella algae H5 (KM007068)

Shewanella upenei N9.2 (JQ670746)

81

Enterobacter hormaechei ChST9.2 (JF935102)

Citrobacter murliniae M-T-MRS_22 (JQ795823)

Citrobacter sp. Z7 (JX185134)

Enterobacter sp. SSBC6 (JQ074014)

55

Citrobacter youngae GTC 01314 (AB741661)

Leclercia sp. BTCZ22 (KF909001)

Klebsiella sp. SUS9K (KF991505)

Citrobacter freundii C09 (KM222617)

-DGGE-10 (LC009478)

Cellulomonas hominis PuiC5.18 (LM994741)

Cellulomonas aerilata JCM 16376 (AB910521)

99 DGGE-9 (LC009477)

Cellulosimicrobium cellulans S17 (KJ947163)

Cellulosimicrobium funkei AR6 (KM263187)

Figure 3 (See legend on next page.) 
(See figure on previous page.)

Figure 3 Phylogenetic tree based on the 16S rRNA gene sequence of the Oryctes agamemnon endosymbiont in relation to closest matches from NCBI GenBank database with corresponding accession numbers given in parentheses. The tree was constructed by the neighbor-joining method using Kimura's correction for multiple substitutions. Percent bootstrap values (1000 resamplings) of their level of support are shown at the individual nodes. The scale bar represents 0.02 substitutions per nucleotide position. The data sets supporting the results concerning phylogenetic analysis are available in the Dryad Digital Repository: http://dx.doi.org/10.5061/dryad.59h51.

we have to answer, what would be resulted in the absence (either intentional or accidental) of each single symbiont or a specific symbiotic group? If this question is correctly answered, this means a successful control strategy for this insect pest is achieved. Therefore, further studies are now required to clarify the biological function of these endosymbiotic bacteria in Oryctes larvae and their potential as novel targets for beetle control.

\section{Methods}

Insects

Oryctes agamemnon larvae were field-collected from a date palm orchard about $80 \mathrm{~km}$ north Almadinah Almunawarah region, of Saudi Arabia at longitude (39 $\left.11^{\prime} 6^{\prime \prime}\right)$ and latitude $\left(24^{\circ} 47^{\prime} 6^{\prime \prime}\right)$. The $3^{\text {rd }}$ larval instar was dominant in sampling. Samples of larvae were collected in sterilized plastic containers. The larvae were kept in the laboratory for one week prior to dissection to avoid possible infestations from the field and to reduce any potential insecticide residual effects. All stages were kept in plastic containers half-filled with soil and date palm pieces. The larvae were dissected in dissection trays containing $0.65 \%$ saline and the midguts were aseptically removed [46]. The midguts were homogenized in a sterile glass homogenizer containing $0.85 \%$ saline. The supernatant suspension was used for bacterial enrichment and DNA extraction. Each sample consisted of the content of three pooled midguts taken from three larvae of the same instar. Metagenomic DNA was extracted from soil infested with larvae for comparative purposes.

\section{DNA extraction and PCR amplification of 16S rRNA genes}

Total community DNA was extracted with the Ultra Clean Soil DNA purification kit (Mo Bio Laboratories, Solana Beach, Calif.). Harvested cells were transferred to bead beating tubes and vortexed horizontally for $1 \mathrm{~min}$ at room temperature. Supernatant was collected and DNA was precipitated and purified according to the instruction manual. Amplification of 16S rRNA genes for DGGE analysis was performed using GC-clamp primers (EUB341F-GC: 5'-CGCCCGCCGCGCGCGGC GGGCGGGGCGGGGGCACGGGGGGCCTACGGGAG GCAGCAGCAG-3' and EUB517R: 5'-ATTACCGCGGC TGCTGG-3') that correspond to positions 341 and 517 in Escherichia coli [47]. Amplification were performed in 25 $\mu \mathrm{l}$ reaction vessel containing: $2.5 \mu \mathrm{l}$ of $10 \times \mathrm{Taq}$ buffer
(100 mM Tris-HCl, pH 8), $1.25 \mathrm{mM} \mathrm{MgCl}_{2}, 100 \mu \mathrm{M}$ dNTPs (Invitrogen, USA), $1.2 \mu \mathrm{M}$ forward primer and reverse primer set (Invitrogen, USA), 0.5U Taq DNA polymerase (Invitrogen, USA), and about $5 \mathrm{ng}$ of template DNA. PCR was performed in Thermal Cycler (Applied Biosystems 2720, USA). A touchdown PCR program was implemented as follows: initial denaturation step at $95^{\circ} \mathrm{C}$ for $5 \mathrm{~min} ; 5$ cycles of $94^{\circ} \mathrm{C}$ for $40 \mathrm{sec}$, annealing at $65^{\circ} \mathrm{C}$ for $40 \mathrm{sec}$, and extension at $72^{\circ} \mathrm{C}$ for $40 \mathrm{sec} ; 5$ cycles of $94^{\circ} \mathrm{C}$ for $40 \mathrm{sec}$, annealing at $60^{\circ} \mathrm{C}$ for $40 \mathrm{sec}$, and extension at $72^{\circ} \mathrm{C}$ for $40 \mathrm{sec} ; 10$ cycles of $94^{\circ} \mathrm{C}$ for $40 \mathrm{sec}$, annealing at $55^{\circ} \mathrm{C}$ for $40 \mathrm{sec}$, and extension at $72^{\circ} \mathrm{C}$ for $40 \mathrm{sec} ; 10$ cycles of $94^{\circ} \mathrm{C}$ for $40 \mathrm{sec}$, annealing at $50^{\circ} \mathrm{C}$ for $40 \mathrm{sec}$, and extension at $72^{\circ} \mathrm{C}$ for $40 \mathrm{sec}$ were performed, followed by a final hold at $72^{\circ} \mathrm{C}$ for $7 \mathrm{~min}$. Amplicons were analyzed by electrophoresis on $1 \%$ agarose gels with the size markers ( $1 \mathrm{~kb}$ DNA ladder, Invitrogen, USA) and visualized using ethidium bromide.

\section{DGGE}

DGGE was performed using Dcode Mutation Detection System (Bio-Rad Laboratories Ltd., Hertfordshire, UK). PCR products were electrophoresed with $0.5 \times$ TAE buffer $(1 \times$ TAE buffer is $0.04 \mathrm{M}$ Tris base, $0.02 \mathrm{M}$ sodium acetate, and $10 \mathrm{mM}$ EDTA [pH 7.4]) on $8 \%$ acrylamide gel containing 25 to $50 \%$ denaturating gradient of formamide and urea. DGGE was conducted at $60^{\circ} \mathrm{C}$ for $5 \mathrm{~h}$ at voltage of $200 \mathrm{~V}$. The gel was stained with SYBR Green I Nucleic acid gel stain (Cambrex Bio Science Rockland, USA), photographed and analyzed for DGGE band profile with a UV gel documentation system (Bio-Rad Laboratories Inc., CA, USA).

\section{Numerical analysis of the DGGE fingerprints}

The DGGE fingerprints were analyzed using Quantity One 1D software (BioRad). The total number of DGGE bands was used to represent OTUs richness [48]. Bacterial diversity was estimated based on densitometric measurements and Shannon diversity index $\left(H^{\prime}\right)[48,49]$, Equation (1)

$$
\begin{aligned}
& H^{\prime}=-\Sigma P_{i}\left(\ln P_{i}\right) \\
& P_{i}=n_{i} / N_{i}
\end{aligned}
$$

where $P_{i}$ is a relative intensity of DNA band in the fingerprint, $n_{i}$ is densitometrically measured intensity of individual DNA band, and $N_{i}$ is the total amount of 
DNA in the fingerprint. The relative intensity of each band $(P i)$ was used to express the relative frequency of each phylotype [50].

\section{Sequencing of DGGE bands}

Dominant DGGE bands were cut off with a sterile scalpel and eluted by incubation in $100 \mu \mathrm{l}$ of TE buffer at $100^{\circ} \mathrm{C}$ for $5 \mathrm{~min}$. Supernatant was used as template for PCR amplification. Reamplification of 16Sr RNA genes from excised DNA fragments was performed using bacterial primers EUB314F without GC clamp and EUB517R. Amplification was verified by electrophoresis on 1\% agarose gel. PCR products were directly sequenced using a BigDye terminator cycle sequencing [51] at GenoScreen sequencing facility (Genoscreen, Lille, France).

\section{Sequence analysis}

The sequences obtained from the 16S rRNA genes were analyzed by Genetyx-Win MFC application software version 4.0. The reference 16S rRNA gene sequences were retrieved from the GenBank database (National Center for Biotechnology Information, National Library of Medicine, USA) [52]. Sequences were compared with their closest matches in GenBank with nucleotidenucleotide BLAST to obtain the nearest phylogenetic neighbors (www.ncbi.nlm.nih.gov/BLAST/). Sequence align ments were performed by Clustal W1.83 XP [53] and phylogenetic trees were constructed using neighbor-joining method [54] using MEGA6 software [55].

\section{Accession numbers and data deposition}

The 16S rDNA sequences identified in this study have been deposited in the GenBank database under the accession numbers LC009469 to LC009479. The data of the phylogenetic analysis are available from the Dryad Digital Repository: http://dx.doi.org/10.5061/dryad.59h51.

\section{Competing interests}

The authors declare that they have no competing interests.

\section{Authors' contributions}

WE carried out the microbiological and molecular analyses, performed the bioinformatics analyses and constructed the phylogeny trees. RI identified and collected the insects in the field and manipulated them for the gut microbiota analyses. Both authors wrote, read and approved the final manuscript.

\section{Acknowledgements \\ The authors acknowledge Deanship of Scientific Research (DSR) at Taibah University, KSA for their financial support of this work. Authors extend their appreciation to Biology Department, Faculty of Science, Taibah University for providing research facilities. We are also grateful to Fares Zayadi for his help in collecting larvae of the date palm root borer.}

\section{Author details}

'Biology Department, Faculty of Science, Taibah University, Almadinah Almunawarah 344, Saudi Arabia. ${ }^{2}$ Microbiology Department, Faculty of Science, Ain Shams University, Cairo 11566, Egypt. ${ }^{3}$ Department of Economic Entomology, Kafrelsheikh University, Kafr El-Sheikh 33516, Egypt.
Received: 14 November 2014 Accepted: 8 April 2015

Published online: 22 April 2015

\section{References}

1. Khalaf MZ, Al Rubeae HF, Al-Taweel A, Naher F. First record of Arabian rhinoceros bettle, Oryctes agamemnon arabicus Fairmaire on date palm trees in Iraq. Agric Biol J N Am. 2013;4(3):349-51.

2. Soltani $R$, Ikbel $C$, Hamouda H. Descriptive study of damage caused by the rhinoceros beetle, Oryctes agamemnon, and its influence on date palm oases of Rjim Maatoug, Tunisia. J Insect Sci. 2008:57:1-11.

3. Gassouma MS. Pests of the date palm (Phoenix dactylifera). 2004. Online at: http://www.cabdirect.org/abstracts/20087207796.html;jsessionid= A371EDEA1C0D18E9CC493B83DB2020DB.

4. Bedford GO. Biology, ecology and control of palm rhinoceros beetles. Ann Rev Entomol. 1980;25:309-39.

5. Samsudin A, Chew P, Mohd M. Oryctes rhinoceros: breeding and damage on oil palms in an oil palm to oil palm replanting situation. Planter. 1993;69(813):583-91.

6. Ehsine M, Belkadhi M, Chaieb M. Seasonal and nocturnal activities of the rhinoceros borer (Coleoptera: Scarabaeidae) in the north Saharan oases ecosystems. J Insect Sci. 2014;14:256-61.

7. Soltani R. The rhinoceros beetle Oryctes agamemnon arabicus in Tunisia: current challenge and future management perspectives. Tunisia J Plant Prot. 2010;5(2):179-93.

8. Lundgren J, Michael R, Chee-Sanford J. Bacterial communities within digestive tracts of ground beetles (Coleoptera: Carabidae). Ann Entomol Soc Am. 2007;100(2):275-82.

9. Ferrari J, Vavre F. Bacterial symbionts in insects or the story of communities affecting communities. Phil Trans R Soc B. 2011;366:1389-400.

10. Hongoh Y. Diversity and genomes of uncultured microbial symbionts in the termite gut. Biosci Biotechnol Biochem. 2010;74:1145-51.

11. Engel P, Moran NA. The gut microbiota of insects - diversity in structure and function. FEMS Microbiol Rev. 2013;37:699-735.

12. Colman DR, Toolson EC, Takacs-Vesbach CD. Do diet and taxonomy influence insect gut bacterial communities? Mol Ecol. 2012;21:5124-37.

13. Duron O, Bouchon D, Boutin S, Bellamy L, Zhou L, Engelstädter J, et al. The diversity of reproductive parasites among arthropods: Wolbachia do not walk alone. BMC Biol. 2008;6:27

14. Hilgenboecker $K$, Hammerstein P, Schlattmann P, Telschow A, Werren JH. How many species are infected with Wolbachia? A statistical analysis of current data. FEMS Microbiol Lett. 2008;281(2):215-20.

15. Zindel R, Gottlieb Y, Aebi A. Arthropod symbioses: a neglected parameter in pest- and disease-control programs. J Appl Ecol. 2011;48(4):864-72.

16. Oliver KM, Degnan PH, Burke GR, Moran NA. Facultative symbionts in aphids and the horizontal transfer of ecologically important traits. Ann Rev Entomol. 2010;55:247e266.

17. Hirsch J, Strohmeier S, Pfannkuchen P, Reineke A. Assessment of bacterial endosymbiont diversity in Otiorhynchus spp. (Coleoptera: Curculionidae) larvae using a multitag 454 pyrosequencing approach. BMC Microbiol. 2012;12(1):S6.

18. Moya A, Pereto J, Gil R, Latorre A. Learning how to live together: genomic insights into prokaryote-animal symbioses. Nature Rev Genet. 2008;9(3):218-29.

19. Moran NA, McCutcheon JP, Nakabachi A. Genomics and evolution of heritable bacterial symbionts. Annu Rev Genet. 2008;42:165-90.

20. Douglas AE. Symbiotic microorganisms: untapped resources for insect pest control. Trends Biotechnol. 2007;25(8):338-42.

21. Beard CB, Mason PW, Aksoy S, Tesh RB, Richards FF. Transformation of an insect symbiont and expression of a foreign gene in the Chagas disease vector Rhodnius prolixus. Amer J Trop Med Hyg. 1992;46:195-200.

22. Avidano L, Gamalero E, Cossa GP, Carraro E. Characterization of soil health in an Italian polluted site by using microorganisms as bio-indicators. Appl Soil Ecol. 2005;30:21-33.

23. Amann R, Ludwig W, Schleifer KH. Phylogenetic identification and in situ detection of individual microbial cells without cultivation. Microbiol Rev. 1995;59:143-69.

24. Head IM, Saunders JR, Pickup RW. Microbial evolution, diversity, and ecology: a decade of ribosomal RNA analysis of uncultivated microorganisms. Microb Ecol. 1998;35(1):1-21.

25. Hugenholtz P, Goebel B, Pace N. Impact of culture-independent studies on the emerging phylogenetic view of bacterial diversity. J Bacteriol. 1998;180:4765-74. 
26. Muyzer G. DGGE/TGGE, a method for identifying genes from natural communities. Curr Opin Microbiol. 1999:2:317-22.

27. Muyzer G, Brinkhoff T, Nübel U, Santegoeds C, Schäfer H, Wawer C. Denaturing Gradient Gel Electrophoresis (DGGE) in Microbial Ecology, p. 1-27. In: Akkermans ADL, van Elsas JD, de Bruijn FJ, editors. Molecular Microbial Ecology Manual, vol. 3.4.4. Dordrecht, The Netherlands: Kluwer Academic Publishers; 1997.

28. Marsh TL. Terminal restriction fragment length polymorphism (TRFLP): an emerging method for characterizing diversity among homologous populations of amplification products. Curr Opin Microbiol. 1999;2:323-7.

29. Gelsomino A, Keijzer WA, Cacco G, Van Elsas JD. Assessment of bacterial community structure in soil by polymerase chain reaction and denaturing gradient gel electrophoresis. J Microbiol Meth. 1999;38:1-15.

30. Riemann L, Steward GF, Fandino LB, Campbell L, Landry MR, Azam F. Bacterial community composition during two consecutive NE Monsoon periods in the Arabian Sea studied by denaturing gradient gel electrophoresis (DGGE) of rRNA genes. Deep-Sea Res. 1999:46:1791-811.

31. Smalla K, Wieland G, Buchner A, Zock A, Parzy J, Kaiser S, et al. Bulk and rhizosphere soil bacterial communities studied by denaturing gradient gel electrophoresis: plant-dependent enrichment and seasonal shifts revealed. Appl Environ Microbiol. 2001;64:1220-5.

32. Ritz K, Mac Nicol JW, Nunan N, Grayston S, Millard P, Atkinson A, et al. Spatial structure in soil chemical and microbiological properties in upland grassland. FEMS Microbiol Ecol. 2004;49:191-205.

33. Sun HY, Deng SP, Raun WR. Bacterial community structure and diversity in a century-old manure-treated agro-ecosystem. Appl Environ Microbiol. 2004;70:5868-74.

34. Whiteley AS, Bailey MJ. Bacterial community structure and physiological state within an industrial phenol bioremediation system. Appl Environ Microbiol. 2000;66:2400-7.

35. Andert J, Marten A, Brandl R, Brune A. Inter- and intraspecific comparison of the bacterial assemblages in the hindgut of humivorous scarab beetle larvae (Pachnoda spp.). FEMS Microbiol Ecol. 2010;74:439-49.

36. Lauzon CR, Sjogren RE, Prokopy RJ. Enzymatic capabilities of bacteria associated with apple maggot flies: a postulated role in attraction. J Chem Ecol. 2000;26:95-967.

37. Adams $L$, Boopathy R. Isolation and characterization of enteric bacteria from the hindgut of Formosan termite. Biores Technol. 2005;96(14):1592-8.

38. Tagliavia M, Messina E, Manachini B, Cappello S, Quatrini P. The gut microbiota of larvae of Rhynchophorus ferrugineus Oliver (Coleoptera: Curculionidae). BMC Microbiol. 2014;14:136.

39. Fujiwara A, Maekawa K, Tsuchida T. Genetic groups and endosymbiotic microbiota of the Bemisia tabaci species complex in Japanese agricultural sites. J Appl Entomol Online. 2014, doi: 10.1111/jen.12171.

40. Desai A, Bhamre P. Diversity of gut bacterial fauna of Oryctes monocerus linnaeus (coleoptera: scarabaeidae). Bionano Front. 2012;5:1-4.

41. Huang S, Sheng P, Zhang H. Isolation and identification of cellulolytic bacteria from the gut of Holotrichia parallela larvae (Coleoptera: Scarabaeidae). Int J Mol Sci. 2012;13:2563-77.

42. Sanchez-Contreras M, Vlisidou I. The diversity of insect-bacteria interactions and its applications for disease control. Biotech Gene Eng Rev. 2008;25:203-44.

43. Chandler J, Lang J, Bhatnagar S, Eisen J, Kopp A. Bacterial communities of diverse Drosophila species: ecological context of a host-microbe model system. PLoS Genet. 2011;7(9):1-18. e1002272.

44. Ovreas L. Population and community level approaches for analyzing microbial diversity in natural environments. Ecol Lett. 2000;3:236-51.

45. Campbell B, Bragg T, Turner C. Phylogeny of symbiotic bacteria of four weevil species (Coleoptera:Curculionidae) based on analysis of $16 \mathrm{~s}$ ribosomal DNA. Insect Biochem Molec Biol. 1992;22(5):415-21.

46. Lemke T, Stingl U, Egert M, Friedrich MW, Brune A. Physicochemical conditions and microbial activities in the highly alkaline gut of the humus-feeding larva of Pachnoda ephippiata (Coleoptera: Scarabaeidae). Appl Environ Microbiol. 2003;69:6650-8

47. Muyzer G, De Waal EC, Uitterlinden AG. Profiling of complex microbial populations by denaturing gradient gel electrophoresis analysis of polymerase chain reaction-amplified genes coding for $16 \mathrm{~S}$ rRNA. Appl Environ Microbiol. 1993;59:695-700.

48. Duarte S, Pascoal C, Garabétian F, Cássio F, Charcosset JY. Microbial decomposer communities are mainly structured by the trophic status in circumneutral and alkaline streams. Appl Enviro Microbiol. 2009:75:6211-21.
49. Ping L, Yanxin W, Yanhong W, Kun L, Lei T. Bacterial community structure and diversity during establishment of an anaerobic bioreactor to treat swine wastewater. Water Sci Technol. 2010;62:243-52.

50. Moreirinha C, Duarte S, Pascoal C, Cássio F. Effects of cadmium and phenanthrene mixtures on aquatic fungi and microbially mediated leaf litter decomposition. Arch Environ Cont Toxicol. 2011:61:211-9.

51. Sanger F, Nicklen $S$, Coulson A. DNA sequencing with chain-terminating inhibitors. Biochemistry. 1977:74(12):5463-7.

52. Altschul SF, Madden TL, Schäffer AA, Zhang J, Zhang Z, Miller W, et al. Gapped blast and psi-blast: a new generation of protein database search programs. Nucleic Acids Res. 1997;25:3389-402.

53. Thompson D, Gibson J, Plewinak F, Jeanmougin F, Higgins G. The Clastal X windows interface: flexible strategies for multiple sequence alignment aided by quality analysis tools. Nuc Acid Res. 1997;25:4867-87.

54. Saitou N, Nei M. The neighbor-joining method: a new method for reconstructing phylogenetic trees. Mol Biol Evol. 1987;4:406-25.

55. Kumar S, Tamura K, Nei M. MEGA3: an integrated software for molecular evolutionary genetics analysis and sequence alignment. Brief Bioinform. 2004:5:150-63.

\section{Submit your next manuscript to BioMed Central and take full advantage of:}

- Convenient online submission

- Thorough peer review

- No space constraints or color figure charges

- Immediate publication on acceptance

- Inclusion in PubMed, CAS, Scopus and Google Scholar

- Research which is freely available for redistribution 